\title{
An outbreak of norovirus infection in a long-term care facility in Brazil
}

\author{
Surto de infecção por norovírus em instituição de longa permanência no Brasil
}

\author{
Fernando Gatti de Menezes ${ }^{1}$, Vanessa Maria da Silva de Poli Correa ${ }^{2}$, Fábio Gazelato de Mello Franco ${ }^{3}$, \\ Miriam Ikeda Ribeiro, Maria Fátima dos Santos Cardoso ${ }^{5}$, Simone Guadagnucci Morillo 6 , \\ Rita de Cássia Compagnoli Carmona ${ }^{7}$, Maria do Carmo Sampaio Tavares Timenetsky ${ }^{8}$, Luci Correa ${ }^{9}$, Jacyr Pasternak ${ }^{10}$
}

\begin{abstract}
Objective: To describe a norovirus outbreak in a Brazilian longterm care facility from July 8 to 29, 2005. Methods: In the first 48 to 72 hours after onset of symptoms in inpatients and employees, the main infection control strategies were staff education, emphasis on hand washing, implementing contact precautions up to 48-72 hours after resolution of symptoms, complete cleaning of the rooms and exclusion of symptomatic employees from work until 48-72 hours after resolution of their symptoms. Epidemiological and clinical characteristics of the norovirus infections were described based on chart review. Results: The incidence among inpatients and employees was $41.3 \%$ and $16.25 \%$, respectively. The main symptom was diarrhea, affecting $100 \%$ of inpatients and employees. Forty-four percent of specimens were positive by RIDASCREEN ${ }^{\circledR}$ Norovirus analyses, and identified as norovirus genogroup Gll. Seventy percent of inpatients were women and their age range was $51-98$ years. Inpatients had in average two comorbid conditions $-87.3 \%$ with cardiovascular or chronic pulmonary condition and $47.6 \%$ with dementia. There was not relapse or death. Conclusions: The early infection-control measures associated to surveillance are required to keep long-term care facilities free of noroviruses and to protect those who are most vulnerable.
\end{abstract}

Keywords: Norovirus; Disease outbreaks; Homes for the aged; Aged; Surveillance

\section{RESUMO}

Objetivo: Descrever um surto de norovírus ocorrido em uma instituição de longa permanência no Brasil, de 8 a 29 de julho 2005. Métodos: Nas primeiras 48 a 72 horas após 0 início dos sintomas entre moradores da instituição de longa permanência e funcionários, as principais estratégias de controle da infecção foram: educação da equipe, reforço na higienização das mãos, implementação de precauções de contato até 48 a 72 horas após 0 término de sintomas, limpeza "terminal" dos quartos dos moradores e afastamento dos funcionários sintomáticos até 48 a 72 horas após o término dos sintomas. As características clínicas e epidemiológicas das infecções por norovírus foram descritas baseadas nos dados dos prontuários. Resultados: A incidência foi $41,3 \%$ entre moradores e $16,25 \%$ entre funcionários. 0 principal sintoma foi diarreia, acometendo $100 \%$ dos casos; $44 \%$ das amostras de fezes foram positivas pela análise RIDASCREEN ${ }^{\circledR}$ Norovirus, com a identificação do norovírus genogrupo II. Setenta por cento dos moradores eram do sexo feminino, com idade de 51 a 98 anos. Os moradores tinham, em média, duas comorbidades, sendo $87,3 \%$ com doenças cardiovasculares ou pulmonares e $47,6 \%$ com demência. Não houve recidiva do surto ou óbitos. Conclusões: As medidas precoces de prevenção associada à vigilância são estratégias que mantém as instituições de longa permanência livres de infecções por norovírus e protegem aqueles indivíduos mais vulneráveis.

Descritores: Norovirus; Surtos de doenças; Instituição de longa permanência para idosos; Idoso; Vigilância

\footnotetext{
Study carried out at the Albert Einstein Long-Term Care Facility of Unidade Avançada Vila Mariana of the Hospital Israelita Albert Einstein - HIAE, São Paulo (SP), Brazil.

${ }^{1} \mathrm{MD}$ at Hospital Israelita Albert Einstein - HIAE, São Paulo (SP), Brazil.

${ }^{2}$ Nurse at Nosocomial Infection Control Committee of Unidade Avançada Vila Mariana of the Hospital Israelita Albert Einstein - HIAE, São Paulo (SP), Brazil.

${ }^{3} \mathrm{PhD}$ in Cardiology; Medical Coordinator of Unidade Avançada Vila Mariana of the Hospital Israelita Albert Einstein - HIAE, São Paulo (SP), Brazil.

${ }^{4}$ Nurse; Manager of Unidade Avançada Vila Mariana of the Hospital Israelita Albert Einstein - HIAE, São Paulo (SP), Brazil.

${ }^{5}$ Master degree in Infectious Diseases; Nurse at Nosocomial Infection Control Committee of Unidade Morumbi of the Hospital Israelita Albert Einstein - HIAE, São Paulo (SP), Brazil.

${ }^{6}$ Master degree in Biology; Biologist at Enteral Virus Laboratory of the Instituto Adolfo Lutz - São Paulo (SP), Brazil.

${ }^{7} \mathrm{PhD}$ in Biology; Head of the Enteral Virus Laboratory of the Instituto Adolfo Lutz - São Paulo (SP), Brazil.

${ }^{8} \mathrm{PhD}$ in Biology; Director of the Virology Department of the Instituto Adolfo Lutz - São Paulo (SP), Brazil.

${ }^{9} \mathrm{PhD}$ in Infectious Diseases; Coordinator of Nosocomial Infection Control Committee of Unidade Morumbi of the Hospital Israelita Albert Einstein - HIAE, São Paulo (SP), Brazil.

${ }^{10} \mathrm{PhD}$ in Infectious Disease; President of the Nosocomial Infection Control Committee of Unidade Morumbi of the Hospital Israelita Albert Einstein - HIAE, São Paulo (SP), Brazil.

Corresponding author: Fernando Gatti de Menezes - Avenida Sousa Reis, 120, apto. 24A - Vila Indiana - CEP: 05586-080 - São Paulo (SP), Brazil - Tel./ Fax: 11 3726-5213 -

E-mail: fermenezes1@hotmail.com

Received: May 23, 2010 - Accepted: Oct 04, 2010

Conflict of interest: none.
} 


\section{INTRODUCTION}

Noroviruses, formerly referred to as Norwalk-like viruses, are important pathogens in hospitals and long-term care facilities outbreaks. It is the most common cause of gastrointestinal disease in the United States, with an estimated 23 million cases occurring annually ${ }^{(1)}$.

Norovirus is extremely infectious and requires a small inoculum to cause the disease (10 to 100 organisms). Transmission of noroviruses during institutional outbreaks can occur via multiples routes, including person-to-person contact, fecal-oral route, consumption of contaminated food or water, aerosolization of viral particles during vomiting and contaminated fomites ${ }^{(2-3)}$.

The incubation period of norovirus gastroenteritis varies from 10 to 72 hours but is usually 24 to 48 hours, and the illness often resolves with 24 to 48 hours but it may last a week or longer. Illness is characterized by diarrhea, vomiting, abdominal pain, malaise, and constitutional symptoms, such as headache, low-grade fever, chills and myalgia ${ }^{(4,5)}$.

Among long-term care facility inpatients, fecal incontinence, dementia, and immobility are common conditions that may facilitate extensive contamination of the environment with the fecal pathogens.

\section{OBJECTIVE}

To describe the characteristics of a norovirus outbreak in a Brazilian long-term care facility using epidemiologic and molecular diagnostic methods and to propose preventive actions.

\section{METHODS}

In July 2005, gastroenteritis outbreaks were notified to the Infection Control Service of the Albert Einstein Long-Term Care Facility, São Paulo, Brazil. This site housed 150 inpatients with 40 clinical staff.

For the purpose of this study, the outbreak was defined as 3 or more related cases with acute onset of diarrhea ( 2 or more episodes in 24 hours). The Kaplan criteria were used for diagnosis of presumptive norovirus infection, including negative stool cultures for bacterial pathogens, vomiting in more than $50 \%$ of cases, an incubation period of 24-48 hours, and a mean or median illness duration of 12-60 hours ${ }^{(1)}$.

Stool samples were collected for culture of Campylobacter spp., Salmonella spp., Shiguella spp., Staphylococcus aureus, Vibrio spp., Yersinia enterocolitica, enteropathogenicEscherichia coli, and antigen detection for rotavirus. Ova and parasites were detected by direct microscopy.
These samples were assayed for the presence of norovirus using the RIDASCREEN ${ }^{\circledR}$ Norovirus kit (R-Biopharm AG, Darmstadt, Germany) following the manufacturer's instructions, and reverse transcriptionpolymerase chain reaction (RT-PCR). The nucleotide sequence of polymerase chain reaction (PCR) (cDNA) products for norovirus was determined with the BigDye terminator cycle sequencing kit and an automated ABI Prism 377 (PE Applied Biosystems, Inc., USA).

For the environment research, samples of water, milk, yogurt, cheese, cakes, salad, potatoes, rice, and other foods were analyzed for culture of Bacillus cereus, Salmonella spp., Staphylococcus aureus, Clostridium spp., and yeast.

\section{RESULTS}

The outbreak occurred from July 8 to 29,2005 , involving 95 cases (62 inpatients and 33 employees). Figure 1 shows the cases for inpatients and employees.

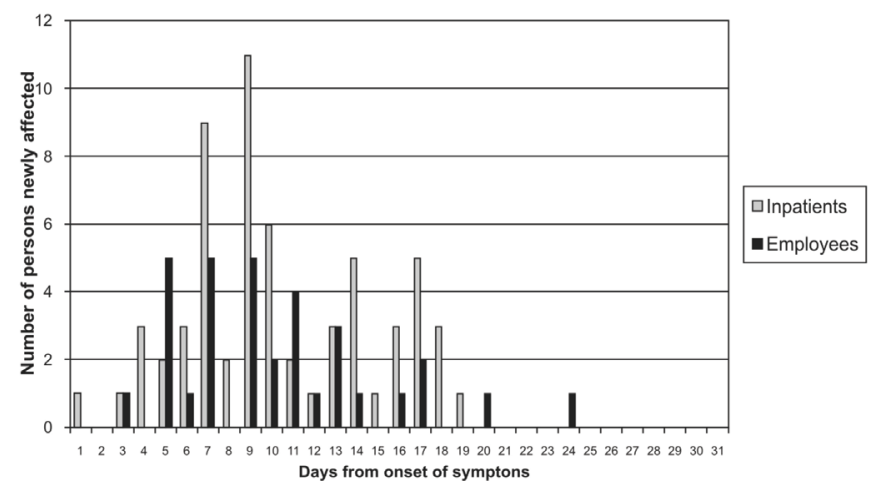

Figure 1. The epidemic curve of the norovirus outbreak in employees and inpatients.

Stool samples from patients with acute gastroenteritis (eight inpatients and one employee) were sent to the Enteral Virus Laboratory of the Instituto Adolfo Lutz, São Paulo, Brazil, to identify the outbreak agent. Among the nine specimens analyzed by RIDASCREEN ${ }^{\circledR}$ Norovirus, 4 (44.4\%) were positive, and identified as norovirus genogroup GII by RT-PCR using the MON 431-433 primer pool. The PCR products $(n=3)$ were analyzed by gene sequencing and confirmed as genogroup GII. Comparison of the sequences obtained with those available in GenBank is the method of choice for genome analysis and characterization of norovirus genogroups according to the proposed classification ${ }^{(6)}$.

Assays for rotavirus, as well as culture of bacteria and tests for parasites were negative. Of all environmental samples tested, the cultures of water were positive for Pseudomonas aeruginosa. 
Among the inpatients, $70 \%$ were women and the age range was 51 to 98 years (median age 83 years). Thirty-five percent of these cases were completely dependent for daily activities. Inpatients had a median of two comorbid conditions (range of 0 to 6 ), $87.3 \%$ with cardiovascular or chronic pulmonary condition, $47.6 \%$ with dementia, $27 \%$ with diabetes, and $12.7 \%$ with any gastrointestinal disorder.

Among the employees, $87 \%$ were women and ages ranged from 21 to 53 years (median age 25 years).

The main clinical feature was diarrhea, which affected $100 \%$ of inpatients and employees. Besides, the others symptoms included nausea or vomiting $(50.4 \%)$. The median duration of clinical symptoms was one day (range of one to three days).

Attack rates among inpatients and employees were $41.3 \%$ and $16.25 \%$, respectively. During the outbreak period, neither inpatient nor employees were transferred to the emergency department of the acute care hospital, and there was no death. There was no relapse in this outbreak.

Within 48 to 72 hours, initial infection control strategies were implemented including the report of outbreak to the Public Health authorities, staff education and involvement in infection prevention, reinforcement of hand washing - alcohol-based hand rub was available at every bedside, implementation of contact precautions for all inpatients until the individual was asymptomatic for 48-72 hours, use of mask when assisting vomiting inpatients or cleaning soiled fomites and guarantee of clean water supply, changing the water contaminated with Pseudomonas aeruginosa and using only bottled mineral water. Terminal cleaning of the rooms was performed using 1:50 hypochlorite (bleach) to water solution in all frequently touched surfaces and exclusion of symptomatic employees from work until 4872 hours after resolution of their symptoms. The recommendation for hand washing was the following: to use liquid soap from a pump and water for 1 minute, to rinse for 20 seconds, and to dry with disposable paper towels, according to review of the infection control in other norovirus outbreaks ${ }^{(1)}$.

\section{DISCUSSION}

Noroviruses are currently recognized by far as the most common viral cause of gastroenteritis. Due to short-term symptoms, the lack of easy diagnostic techniques, and insufficient clinical documentation at the long-term care facility combined with limited ability to conduct direct inpatient interviews may have resulted in underestimate of the attack rate among inpatients $^{(7)}$.
In the present study, only 4 of 96 cases tested positive for norovirus. During an ongoing outbreak, it is not possible to obtain stool specimens from all patients involved; patients caring for themselves often forget to obtain specimens or in short course of infection might not provide an opportunity to obtain specimens. Nevertheless, the possibility of norovirus infection cannot be ruled out in the group of norovirus positive cases without symptoms, because approximately $30 \%$ of infected individuals may be asymptomatic ${ }^{(2,8)}$.

The PCR products were sequenced for confirmation of the amplified products and characterization of the genogroups of the norovirus isolates identified in the outbreaks. On the basis of the analysis and comparison of the nucleotide sequences of the POL region, noroviruses are classified according to the degree of similarity between sequences: $>85 \%$ of similarity for GI samples and $>90 \%$ of similarity for GII samples. Most of our samples presented more than $90 \%$ of sequence similarity with GII samples available in GenBank, confirming GII genogroup ${ }^{(9-13)}$.

Norovirus gastroenteritis, although generally a mild, self-limited disease, can be less benign when patients are older, immunocompromised or with cardiovascular disease. Complications may include acute renal failure, rejection, arrhythmias, hypokalemia, and chronic diarrhea. In our outbreak, there was no complication and death among the cases ${ }^{(14)}$.

The person-to-person transmission may have played an important role in our outbreak. Inpatients and employees in long-term-care facilities usually have frequent contact during meals and others activities. Airborne or fomite transmission may also facilitate the spread of the virus during outbreaks. Such hypothesis is confirmed by the attack rate in the employees working in close contact with inpatients ${ }^{(5,14)}$.

The presence of contamination by Pseudomonas aeruginosa in water supply was not the cause of this outbreak, because in our microbiological analysis among inpatients and employees it was not the causative agent of this infection.

Although the data on alcohol-based cleansers suggest that they are insufficient for noroviral disinfection, the use of alcohol hand rubs in our outbreak contributed to reinforcement of hand hygiene and other precaution measures.

The main focus of controlling this outbreak were staff education, hand hygiene, implementation of contact precautions and having employees not back to work until 48-72 hours after their symptoms were resolved $^{(14,15)}$.

This investigation had several limitations. The hand hygiene practice was not audited. No specific test for novovirus was performed on environmental samples, 
limiting the knowledge of the outbreak source. However, we believe that environmental surface contamination may have played a significant role in the persistence of this outbreak, due to presence of fecal incontinence, immobility, and dementia among inpatients. Besides, the ability of noroviruses to persist in the environment for perhaps even three to four weeks may have contributed to the high number of outbreaks ${ }^{(14)}$.

Prevention and control efforts should focus on the potential transmissionmodessuggested byepidemiologic investigation. Aggressive interventions at the onset of an outbreak may be necessary to reduce both morbidity and cost. Therefore, combating this common infection requires marked diligence in public health education and infection-control measures. Vigilance in surveillance, isolation, and disinfection is required to keep the longterm-care facilities free of noroviruses and to protect those who are most vulnerable.

\section{CONCLUSIONS}

The clinical and epidemiological characteristics of the norovirus outbreak were identified and preventive actions were proposed.

\section{ACKNOWLEDGMENTS}

The authors would like to thank Audrey Cilli and Adriana Luchs for the assistance at the Adolfo Lutz Institute.

\section{REFERENCES}

1. Said MA, Perl TM, Sears CL. Healthcare epidemiology: gastrointestinal flu: norovirus in health care and long-term care facilities. Clin Infect Dis. 2008;47(9):1202-8.
2. Cooper $\mathrm{E}, \mathrm{Blamey} \mathrm{S}$. A norovirus gastroenteritis epidemic in a long-term-care facility. Infect Control Hosp Epidemiol. 2005;26(3):256-8.

3. Boccia D, Tozzi AE, Cotter B, Rizzo C, RussoT, Buttinelli G, et al. Waterborne outbreak of Norwalk-like virus gastroenteritis at a tourist resort, Italy. Emerg Infect Dis. 2002;8(6):563-8.

4. Centers for Disease Control and Prevention (CDC). Norovirus activity - United States, 2006-2007. MMWR Morb Mortal Wkly Rep. 2007;56(33):842-6.

5. Parashar U, Quiroz ES, Mounts AW, Monroe SS, Fankhauser RL, Ando T. "Norwalk-like viruses". Public health consequences and outbreak management. MMWR Recomm Rep. 2001;50(RR-9):1-17.

6. Castilho JG, Munford V, Resque HR, Fagundes-Neto U, Vinjé J, Rácz ML. Genetic diversity of norovírus among children with gastroenteritis in São Paulo State, Brazil. J Clin Microbiol. 2006;44(11):3947-53.

7. Navarro G, Sala RM, Segura F, Arias C, Anton E, Varela P, et al. An outbreak of norovirus infection in a long-term-care unit in Spain. Infect Control Hosp Epidemiol. 2005;26(3):259-62.

8. Goller JL, Dimitriadis A, Tan A, Kelly H, Marshall JA. Long-term features of norovirus gastroenteritis in the elderly. J Hosp Infect. 2004;58(4):286-91.

9. Morillo SG, Cilli A, Carmona RC, Timenetsky MCST. Identification and Molecular Characterization of Norovirus in São Paulo State, Brazil. Braz J Microbiol. 2008;39(4):619-22.

10. Gouvea V, Santos N, Timenetsky Mdo C, Estes MK. Identification of Norwalk virus in artificially seeded shellfish and selected foods. J Virol Methods. 1994;48(2-3):177-87.

11. Fankhauser RL, Monroe SS, Noel JS, Humphrey CD, Bresee JS, Parashar UD, et al. Epidemiologic and molecular trends of "Norwalk-like viruses" associated with outbreaks of gastroenterits in the United States. J Infect Dis. 2002;186(1):1-7.

12. Zheng DP, Ando T, Fankhauser RL, Beard RS, Glass RI, Monroe SS. Norovirus classification and proposed strain nomenclature. Virology. 2006;346(2):31223.

13. Chomczynski P, Sacchi N. Single-step method of RNA isolation by acid guanidinium thiocyanate-phenol-chloroform extraction. Anal Biochem. 1987;162(1):156-9.

14. Mattner F, Sohr D, Heim A, Gastmeier P, Vennema H, Koopmans M. Risk groups for clinical complications of norovirus infections: an outbreak investigation. Clin Microbiol Infec. 2006;12(1):69-74.

15. Gilbride SJ, Lee BE, Taylor GD, Forgie SE. Successful containment of a norovirus outreak in an acute adult psychiatric area. Infect Control Hosp Epidemiol. 2009;30(3):289-91. 